\title{
The Chemistry of Mobile Phones: A Research Report on the Extent of Usage of the Compact Technology among Students on Nigerian Campuses
}

\author{
Oyewusi Lawunmi Molara ${ }^{1, *} \&$ Adamu Boladale Joseph ${ }^{2}$ \\ ${ }^{1}$ Department of Educational Technology, Obafemi Awolowo University, Ile-Ife, Osun State, Nigeria \\ ${ }^{2}$ Department of Primary Education, College of Education, Ikere-Ekiti, Nigeria \\ *Corresponding author: Department of Educational Technology, Obafemi Awolowo University, Ile-Ife, Osun State, \\ Nigeria. E-mail: oyewusilawunmi@yahoo.com
}

Received: July 5, 2014

doi:10.5430/wje.v4n4p38
Accepted: July 23, $2014 \quad$ Online Published: July 31, 2014

URL: http://dx.doi.org/10.5430/wje.v4n4p38

\begin{abstract}
When many authors were referring to radio and television as 'new media' some years ago, little did they realize that a group of media, will later emerge that will sooner be termed 'newer'. The new development is about the adoption of mobile phones. These trends have emerged in many social contexts including participation in social networks, changes in the traditional communication habits and exhibition of unanticipated behaviours resulting from mobile communication. Nigeria, like every other nation is not relenting her efforts in moving with time. When mobile phones first came into Nigeria, many felt it will wipe off the telecommunications company which was statutorily on ground, today, the technology is making life easy for young and old.

This study is an addition to the relevant literatures on media research especially the accommodation of ubiquitous technologies on Nigerian campuses. It will draw attention to the ways Nigerian students use mobile phones and investigate attitudes about mobile phone usage in public settings. Although, it might look as if nothing new is been described that is not common in other settings, this seem to be the first time that the youth will take the lead in the adoption of an innovation in Nigeria, leaving the trend unexplainable to the adults.

It started with a discussion on the features of phones and moves to present some literature relevant to mobile phone usage. The study found out that students make use of phones everywhere including restricted spaces like banking halls, cars and lecture rooms. Some confessed to causing accidents on campus because they were engaging phones while driving. The study however recommends educational discussions on mobile phones to enhance students' positive and moderate usage of the technology.
\end{abstract}

Keywords: multicommunicating; tethering; mobile phone

\section{The Chemistry of Mobile Phones/Background to the Study}

Pichardo (2012) described mobile phones composition in his summary. He said: 'The potential for mobile phones grows when you think of them as powerful hand held computers, complete with camera, speakers and a whole host of educational apps.... If truly phones are computers, then they must majorly be composed of (i) a display screen (ii) a keyboard and a (iii) processor or a central processing unit. Camera, speakers, stop watch, flex and calculator are built in to complement the technology.

Mobile phones also have other components which are electronic in nature. Prominent among these are the battery and the memory chip. The battery provides the energy required to power the phones while the memory chip stores information for the phones operating system and things that can be user customized. All the parts of a phone are very important and relevant-to-talk-about. When one part is defective, the whole system might be defective. This makes mobile phone as small and as movable as they are, to be an interesting innovation to study.

They easily get spoilt. Not all are rugged. They also get lost mainly because of their sizes. They are easily stolen irrespective of whether they are cheap or expensive. They put food on the table for many. For example because of 
the fragile nature of their parts, a group of people emerged, receiving their daily bread in Nigeria through the sales of phones' accessories. One may be tempted to conclude that because of the points listed above, one should discard the use of phones, but the pluses according to optimists are more than the minuses. So, you can buy as many phones as possible within a short period. It makes sense to say that the use of mobile phones is more useful to education rather than a machine that belongs to school which students will leave behind at the end of the day, mobile phones are handy because students are always with them even outside the school hours.

All the parts are replaceable although at a cost. From interaction with mobile phone users, (mainly students), the parts or the accessory that they replace commonly are the battery and the screen. Many confessed that some expensive phones like 'Blackberry' and 'Android' came with 'not too strong' battery that needs replacement from time to time. Many believe that the batteries run down as a result of over usage. The questions therefore arise: to what extent do Nigerian undergraduate students use mobile phones?, Is there any reason for the recent attachment to mobile phones?

The study has chosen the university as focus because of three major reasons: (i) parents are mindful of 'age' in allowing their teenagers or secondary school students to use mobile phones. The teenagers in the boarding schools are only allowed to utilize phones during holidays while the parents withdraw them as soon as the teenagers are ready to go back to school. A day student on the other hand who utilizes mobile phone(s) only strive to smuggle it into the classroom. (ii) The university students are expected to be more matured in age and experience, recognizing the educational values of phones. (iii) There is a recent attachment to phones by university - aged students which appear to be strange and needs investigating.

Mihailidis (2014) concluded that 'college students are at a formative stage in their lives, where particular worldviews tend to be more engagement - based.... Exploring this particular stage in life of young people can illuminate the use of mobile phones for daily engagement in digital culture, he added. This is why this study has specially chosen a research whereby the extent of mobile phones are investigated among the university - aged - students.

\section{The Unguarded Intimacy}

The scenarios in Nigeria is not different from the one Mihailidis (2014) described in his study where he explores the role of mobile phones in the daily life of young people in the United States. In fact, this is about the first time that our grasp of a technology will be hundred percent (100\%) in terms of intimacy. With the other technologies, we part with them after utilizing them for a little while. Mihalidis described a breed 'checking phones literally every 2 to 3 minutes and a bundle who are diligent about returning wall posts, tweets, comments and other feeds without ceasing.

The phase 'Extra Cool' is not new among Nigerians especially those in the media who have been watching the nail-biting development. Adults began to observe with keen interest the engagement with media leaving the teeming youths sleepless between the hours of twelve in the morning till four the same day (12.00 - 4.00am) Nigerian time. The calls by design was free and an adult will begin to wonder what the 'unstoppable gists' was all about. The 'slogan - 'We are 'talking people' filled the whole atmosphere. The question when the service was on were many: (i) what made the facilitators to fix the engagement time within those hours? (ii) What is 'cool' about an engagement that will leave one sleepless for hours while the eyes will be swollen in the morning? Yet, the crowds were able to cope. Today, the engagement is dying down gradually for a related development - tapping of phones' keyboard.

The recent development among the youths in Nigeria, among who are undergraduates is the tapping of phones from time to time. These engagements or what this study will call unguarded intimacy' they carried into worship grounds like churches, fellowships and mosques. The adults could not stop these engagements. It is not a new thing to queue up in front of a public toilet waiting for a user who is busy inside pressing or tapping a phone. Turkle (2006) in Mihailidis (2012) described this growing dependence as "tethering" which is further painted as "the reliance on technology to facilitate self-worth, community and communication. She concluded: "our new intimacy with machines compels us to speak of a new state of the self, itself..... new place for the situation of a tethered self' (p.1). She saw this growing dependence on mobile phones as an act of self-establishment, where youth, through their mobile devices 'turn other persons into 'self-objects' to shore up their fragile sense of self' (p. 128).

Among the universities' students, using expensive phones like 'Blackberry' or 'Android' has become a symbol of social status. Although the intent of this study is not to review Mihailidi's study, one cannot however but mention some of his views. To him, the attachment is mere of a civic engagement - moved by a necessity or a bid to respond in large-scale to political or civil injustices. Actually, it looked like it! but such move can be diverted into the classroom as well. This study would not want to join the school of thought who believes that the use of mobile 
phones in the classroom is a mirage, but how can mobile phones be diverted into such use? From investigations, at the secondary school level where its usage has been 'tried out' on a small scale in Nigeria, the 'customized mobiles' were 'rooted' by the students, defeating the whole purpose of making them educational. This however should not bring discouragement to the educational sector. Other media like the television and the films started by being media of entertainment. The intimacy is global and lightly expressed in Mihailidis' write up where he commented:

\section{The implications of this attachment to phones permeated all parts of daily life, to the point where students mentioned, "hearing false ringtones, feeling vibrations in pockets where phones aren't...refreshing Twitter and Facebook upwards of 40 times an hour.}

The situation is not different in Nigeria among the youths. In fact, 'collaborativeness' - a feature that has been sparingly evident among students is now made a common occurrence. Another dimension into which the students use the phones is portrayed in the way they carry them into spiritual realm. From investigation, some Nigerian youth now practice what they call 'Conference Prayer. 'Multi-communicating'- a term given to a scenario whereby two or more people come together utilizing their mobile or smart phones in the place of prayer. In all of these, we see leaves to be borrowed in the educational sector. Grinols and Rajesh (2014) summed this up when they wrote:

Since instructors have more (if not always complete) control of students' learning time and environment inside the classroom than they have of students' outside - class learning time or environments, developing opportunities where smartphones are tools to encourage learning may find more acceptance than attempts to ban phones from the classroom (p. 89).

\section{Mobile Phone Use and the Issue of Age}

Bianchi and Phillips (2005) in their findings pointed out that time spent on mobile phone usage during the week is a function of age. In their study, it appears that younger people experience more problem use of the technology because they use mobile phones more. This to them and to Brickfield (1984) is partly due to cultural factors in that younger people are more inclined than older people to embrace new technologies. Buzzard et.al (2011) on the other hand in their own study reported that while students prefer more-traditional instructional technology for effective-engagement and learning, faculty members prefer the use of course-learning technology offered by their universities. This however, they termed 'potential mismatch' between preferences of students and that of teachers.

Looking at these two studies, this report will conclude that embracing technology more than anything else is a function of interest and purpose. One paramount thing that is noteworthy is that youths are more associated with problems related to mobile phone usage. Bianchi and Phillips (2005) referring to Chartton et al (2002) posited that mobile phones are being used to violate privacy and to harass others. However, these increasing evidence is in the developed countries like the United States and the United Kingdom where - Chartton et al (2002) reported that mobile phones are used as a tool by children to bully other children. Oyewusi and Orolade (2014) in their own study carried out in Nigeria found out that although students in the secondary schools in Nigeria at present might be aware of the word "cyberbullying" but the consciousness have not been known to them like the traditional or physical bullying.

\section{Mobile Phone Usage and Academic Achievement}

Peterson et al (2002), citing studies examining technology and its linkages to learning outcomes concluded that 'one of the most striking, yet disturbing observations is that despite the vast number of studies that have been conducted in attempts to evaluate the effectiveness of various instructional technologies used in higher education, no definitive conclusion is possible as to whether instructional technology generally contributes positively to student learning (p. 13).

Bour (2010) describes a scenario while a student sitting in a lecture room is simultaneously reading and responding to a text. Such a student to him is likely to fail in absorbing the lecture during the texting process. Jarmon (2008) supported this when he posited: without effective "self-monitoring strategies", multitasking impedes learning (p. 35). Research indicates that loss in focus due to multi-tasking inhibits tasks as varied as driving to memorization (Abrams, 2013). Study of working memory capacity and problem solving shows that while analytic reasoning benefits from focused attention, more creative thinking could be harmed by too much focus. (Wiley al Jarosz, 2013 p. 261). 


\section{Research Methodology}

\subsection{Population and Sample}

Four hundred undergraduate students were randomly selected for this study which took place on four Nigerian University Campuses. Of the entire sample, 48\% (n-192) were male, while 52\% ( $n=208)$ were female. The respondents were spread across academic disciplines. Several spaces were chosen ranging from their lecture rooms, hostels, amphi theatre, libraries and the banking halls within the campus. All the respondents $(100 \%)$ of the sample owned mobile phones, of which some were smartphones that offered apps while some were internet-enabled phones. The study used a simple questionnaire and observation method. Respondents who are mainly university students and whose age range fall between 18 and 30 participated in this study. The survey spread across academic disciplines ranging from Education, Social Sciences, Administration, Law, Humanities, Engineering and Health Sciences.

\section{Results and Discussions}

All the respondents $(100 \%)$ confessed that they are not supposed to use mobile phones in the lecture rooms. More than half of them (68\%) - 272 in number however confessed that they still use their mobile phones in the lecture rooms despite the ban. They indicated that they used phone more outside the lecture room. This probably may be due to the fact that some lecturers frown at its usage in the lecture room. Some of the things they indicated they do with the phones include: (i) browsing in the internet (ii) short text messaging (sms) (iii) voice calls (iv) listening to music (v) camera and video recording (vi) capturing lecture notes (vii) playing games (viii) voice recording (ix) responding to Facebook messages and tweets. Sixty of them (15\%) confessed that they own a car which they drive on their respective campuses. All of them indicated that they respond to calls, Facebook messages and tweets while driving. Eight of them (2\%) confessed that they had caused - accident on their campuses as a result of the act. This number too could have reduced because those that are car owners among the students reiterated that there is a fine for causing accident on campus.

Respondents also reacted to whether they use phones in the banking halls despite the restrictions. Two hundred and thirty-six of them (59\%) attested to the fact that they use mobile phones even in the banking halls. When asked about the reason(s) why they defer the order, those who indicated that they use their phones in the banking halls also indicated that they find it difficult to do without their mobile phones. Lastly, about two hundred and forty respondents (60\%) indicated that given every opportunity, they will use their mobile phones in the toilet while the remaining forty percent indicated otherwise.

\section{Conclusions and Recommendations}

This study has outlined the extent of usage of mobile phones among students on Nigerian - campuses. Virtually every university student has a mobile phone or a smartphone. Each individual has different things they do with the phone ranging from voice calls, short text messaging, listening to music and responding to Facebook messages and tweets to mention but a few. Banning phones has proven impractical among the students as they use them in places like banks, lecture rooms and even inside their cars. Because their ban in the lecture rooms has failed, lecturers run the risk of phones having detrimental effect during classes. There is also the risk of having outside distraction. Curtailing the use while driving has also proved abortive. The study recommendations are as follows:

- $\quad$ The authorities should create ways to make mobile phones/smartphones' usage contribute to the learning environment.

- Workshops should be organized where educational discussion on the use of the compact technology will be presented. This would provide better context for understanding their use of these devices both inside and outside the lecture rooms.

\section{References}

Abrams, L. (2013, January 28). If you multitask often, you're impulsive and bad at multitasking. The Atlantic, Retrieved from http://www.TheAtlantic.Com/health/archive/2013/01/study-if-you-multitask-often-you are-impulsive- and -bad-at-multitasking/272485!

Binchi, A., \& Phillips, J.G. (2005). Psychological Predictors of Problem. Mobile phone use. Cyberpsychology and Behaviour, 8(1), 39-51. http://dx.doi.org/10.1089/cpb.2005.8.39 
Bour, S. (2010). Technology Untangled: texting is not just for teens. Indiana Lawyer. Retrieved from http://www.theindianalawyer.com/technology-untangled-texting-is-not-just-for-teens/PARAMS/article/23729

Brickfield, C.F. (1984). Attitudes and perceptions of Older People. In: Robinson, P.K, \& Birren, J.E. (eds.), Aging and Technological Advaxes. New York: Plenum, pp. 31-38. http://dx.doi.org/10.1007/978-1-4613-2401-0_4

Buzzard, C., Crittenden, V.L., Crittendon, W.F., \& McCarty, P. (2011). The Use of Digital Technologies in the Classroom: A Teaching and Learning Perspective. Journal of Marketing Education, 33(2), 131-139. http://dx.doi.org/10.1177/0273475311410845

Chartton, T., Parting, C., \& Hannan, A. (2002). Mobile Telephone Ownership and Usage among 10 and 11 year olds. Participation and exclusion. Emotional and behaviour Difficulties, 7, 152-163.

End, C.M., Worthman, S., Mathews, M.B., \& Wetterau, K. (2010). Costly Cell Phones: The Impact of Cell Phone Rings on Academic Performance. Teaching of Psychology, 37(1), 55-57. http://dx.doi.org/10.1080/00986280903425912

Gingerich, A.C., \& Lineweaver, T.T. (2014). OMG! Texting in Class = U Fail: Empirical Evidence That Text Messaging during Class Disrupts Comprehension. Teaching of Psychology, 42(1), 44-51. http://dx.doi.org/10.1177/0098628313514177

Grinols, A.B., \& Rajesh, R. (2014). Multitasking with smartphones in the College Classroom. Business and Professional Communication Quarterly, page 90-95. http://bcq.sagepub.com/content/77/1/89

International Telecommunication Union (2005) 'ICT' Statistics. Retrieved 25 July 2006 from http://www.itu.int/itu-d'/ict/statistics/

Jarmon, A.L. (2008). April. Multitasking: Helpful or Harmful? Student Lawyer, 36(8), 31-35.

Jose P. (2012). Smartphones in the Classrooms: Teachers share their tips.http://www.Theguardian.Com/teacher-network/2012/sep/10/mobile phones

Mihailidis, P. (2013). A tethered generation: Exploring the role of mobile phones in the daily life of young people. Mobile Media and Communication, page 59-72.

National Safety Council. (2012). Annual Estimate of Cell Phone Crashes 2010. Retrieved from http://www.nsc.org/safety-road/distracted-Driving/Documents/Attributable\%20Risk\%20summary.Pdf

Oyewusi, L.M., \& Orolade, K.S. (2014). Cyberbullyfing: A Disruptive Behaviour in Modern Day Classroom. Journal of Educational and Social Research, 4(5) (In Press).

Parry, D. (2011). Mobile Perspectives: On Teaching Mobile Literacy. EDUCAUSE Review, 46(2), 14-16.

Peterson, R.A., Albaum, G., Munuera, J.L., \& Cunningham, W.H. (2002). Reflections on the use of Instructional Technologies in Marketing Education. Marketing Education Review, 12(3), 7-17.

Reinschs N. L. Jr, Turner, J.W., \& Tinsley, C.H. (2008). Multicommunicating: A Practice whose time has come? Academy of Management Review, 33, 391-403. http://dx.doi.org/10.5465/AMR.2008.31193450

Rheingold, H. (2008b). Mobile Media and Political Collective Action. In J. Katz (Ed.). The Handbook of Mobile Communication Studies (pp.225-240). Cambridge M.A.: MIT Press.

Scott, W.C. (2007). A Cross-cultural Comparison of Perceptions and Uses of Mobile Telephony, New Media and Society. Retrieved from http://nms.sage.pub.com/page 343-361

Shah, D.V., McLead, J.M., \& Lee, N. (2009). Communication Competence as a Foundation for Civic Competence: Processes of Socialization into Citizenship. Political Communication, 26, 102-117. http://dx.doi.org/10.1080/10584600802710384

Turkle, S. (2006). Always on/always on you: The tethered Self. In J. Katz (Ed.), Handbook of Mobile Communication and Social Change, 1-21. Cambridges MA: MIT Press.

Wei, R., \& Lo, V. H. (2006). Staying Connected while on the move: Cell phone use and Social Connectedness. New Media Society, 8(1), 53-72. http://dx.doi.org/10.1177/1461444806059870

Wiley. J., \& Jarosz, A.F. (2012). Working Memory Capacity, attentional focus, and Problem Solving. Current Directions in Psychological Sciences, 21, 258-262. http://dx.doi.org/10.1177/0963721412447622 